\title{
Corporate Sustainability Indexes: Dow-Jones Index
}

Drita Krasniqia Luan Vardari ${ }^{\mathrm{b}}$

a Prizren "UKSHIN HOTI" University, Faculty of Economics, Prizren, Kosova, drita.krasniqi@uni-prizren.com

b Prizren "UKSHIN HOTI" University, Faculty of Economics, Prizren, Kosova, luan.vardari@uni-prizren.com

\section{Keywords}

Corporate sustainability, Dow Jones, Time Series,

Financial Markets.

\section{Iel Classification} Q56, C22, C43, D53.

\begin{abstract}
Corporate Sustainability Performance Measurement along with Corporate Environmental Sustainability aims to address the social and economic aspects. Concerns emerging from the three dimensions are being reduced to a single dimension of them. Multi-criteria decisionmaking methods, suggests a useful framework for assessing the variables together. Corporate sustainability and economic business activities are focused on the social and environmental impacts. In this sense, the economic activity established by the businesses do follow social and environmental impacts, therefore the generation of related information of these effects is being considered essential on the structure formation on a sustainable business. In this study, it has been used Dow Jones Sustainability Index monthly data from 2009 to 2015 in a range of 12 months to help investors to make decisions. The comparison of ARIMA and Exponential Smoothing models has been conducted, wherein the results showed that ARIMA model provided better estimates meantime those who invested in a stock portfolio with the same composition as the DJSI proved to ensure positive earnings. The purpose of the essay is to give a conclusion to the future of the practice.
\end{abstract}




\section{Journal of Accounting, Finance and Auditing Studies 4/4 (2018) 1-10}

\section{Introduction}

The concept of sustainability is one of the most widely spoken and spoken concepts that hit last century's stamp. Sustainability as a concept; economic development, social development and protection of the environment. Recalling predominantly economic development; sustainability is in fact directly related to the activities of economic decisionmaking units.

We give the name of economic decision-making units; households, companies, the state and the outside world have also received civil society organizations together with new economic arrangements. Today's modern businesses are for sustainable profitability; economic, ecological and social framework as a part of its strategic plans. It would be possible for public authorities to reflect this structural change to the institutions and organizations in the whole country's economy by looking at the concept of sustainability from a more institutional perspective and by regulating political practices accordingly (Yönet, 2010: 243).

Sustainability indices have become the most important decision-making criterion for global investors. In the reviewed literature it has been found that it is important to create a predictive mechanism for quotations of these indices.

López and the others (2007) , conducted a study to analyze whether business performance was affected by adopting CSR practices. To measure performance, it is considered a group of companies that are part of DJSI and another group involved in DJGI. It has been identified that a negative impact is produced in short-term performance.

Knoepfel (2001), in the study states that "A deeper comparison between the DJSGI and its index components, the Dow Jones Global Index (DJGI), shows a better return on equity, investment and assets for sustainability companies".

In general, ARIMA (autoregressive integrated moving average) is one of the most widely used time series models of these articles (McKenzie, 1984). Although the ARIMA model is sufficiently flexible, it is the most prevalent linear model to form the previously assumed linear form. The ARIMA model utilizes the BOX-Jenkins methodology to create a model (Jenkins, 1970). The greatest advantage of the ARIMA model is that it can be applied to a variety of top-down correction models. 


\section{Journal of Accounting, Finance and Auditing Studies 4/4 (2018) 1-10}

\section{Global Social Sustainability}

According to Benkoltd (2013), while 1\% of the human population holds $40 \%$ of total wealth, the poorest $50 \%$ of human beings have only $1 \%$ of total wealth. These figures also show that half of the world's population lives under the United Nations Line of Poverty. The stratification of society will increase if all resources of the earth are consumed proportionately and this consumption is only in the hands of a certain lumen. For this reason, society needs to be able to continue their lives within the social contract and by adding an account to later generations for the continuation of a human life (Sarikaya and Kara, 2007: 225).

Sustainability; to be able to stay in the race, to be able to stay in the race, and to continue to exist. Global understanding of the concept of sustainability has been thanks to the "Common Future" report, also known as the Butland Report, published by the World Commission on Environment and Development in the United Nations in 1987. The definition of sustainability in the context of "sustainable development" is as follows: Humanity; (Akar and Çamlıca, 2014), without endangering the ability of nature to respond to the needs of future generations, ensuring daily necessities and sustaining development. Sustainable development is defined by the World Commission on Environment and Development as "the ability of today's human needs to be met without sacrificing the ability of future generations to meet their needs" (UN, 1987). Corporate sustainability, on the other hand, is a concept that expresses the continuity of commercial enterprises that include only a part of sustainable development - in particular economic decision units responsible for production (Kuşat, 2012: 229).

\section{Corporate Social Sustainability}

Social Sustainability; food and shelter, as well as cultural and social obligations such as security, equality, health, freedom, education and employment (Tüm, 2014: 51). Sustainability The human dimension to improve the social dimension includes human groups such as business people, society, local people, suppliers and stakeholders. These groups are taken into account in the strategy, mission, vision and practices of the operator (Eş, 2008: 12).

Strategies and practices that can be made by employees at the social dimension are determined by SAI. Social Accountability 8000 (1998): London was revised in 2002. 


\section{Journal of Accounting, Finance and Auditing Studies 4/4 (2018) 1-10}

International Social Accountability is a standard for social accountability and workplace working conditions created by the institution (Aydemir, 2007: 29).

In today's work, quality products and services are not produced in environments where employees are unhappy. Factors such as long working hours, insecure places of work, low wages and discrimination are not accepted by new management systems. The success of companies is now measured not only by the commercial criteria, but also by the concept of social responsibility, that is to say, whether they are contributing to collective action. The voluntary contribution of companies to a better society and a better environment is called corporate social responsibility. For this reason, SA 8000 operators have defined a number of conditions in which they must comply (Kavi, 2010: 32):

- Unions Establishment and Collective Bargaining: Employees have the right to form a trade union, to join a union and to bargain collectively, this right cannot be prevented.

- Child Occupant: Child workers cannot be employed under 15 years of age. If the occupation of this age continues, the total time spent on the job cannot exceed 10 hours per day.

- Forced Labor: The enterprise cannot forcibly operate an occupation or ask employees to leave their identities or a certain deposit business.

- Working Hours: Occupations cannot be operated more than 48 hours per week, overtime cannot exceed 12 hours.

- Salaries and Fees: Fees should be at least equal to the country's "minimum wage" level and meet the basic needs of the staff.

- Health and Safety: The business has to provide a healthy work environment, take preventive measures for accidents and injuries, provide health and safety training, clean sanitation facilities and potable water.

- Discrimination and disciplinary practices: Occupations include sex, ethnicity, etc. cannot be subject to different treatment for reasons and beating, physical and psychological pressure cannot be applied. 


\section{Journal of Accounting, Finance and Auditing Studies 4/4 (2018) 1-10}

\section{The Importance of Corporate Sustainability}

Social sustainability; human and social capital. While human capital is concerned with the individual aspects of employees and business partners such as ability, motivation and loyalty, social capital focuses on the quality of public services, such as supporting a good education system, infrastructure or entrepreneurship. From this point of view, socially sustainable businesses are businesses that have contributed to the development of social capital by promoting both the human capital of their partners and supporting social goals (Dyllick and Hockerts, 2002: 134).

Social sustainability; allows stakeholders to understand the objectives of the business and to be in great compliance with the value system of the business. This will strengthen the social acceptability and legitimacy of the business (Dahlsrud, 2006: 41). By placing institutional sustainability as a culture within the enterprise, it is possible to extend the lifetime of the enterprise and the sum of the increased operating lifetimes will reflect increasing sustainability in the country's economy. Corporate culture is; corporate information management and transfer will be a value that can be gained in business by evaluating the internal elements of corporate sustainability expressed in the form of corporate learning, corporate value, corporate happiness, corporate citizenship, corporate reputation, corporate social responsibility, corporate governance and corporate social capital (Caroll and Shabana, 2003: 87).

\section{Dataset}

We have taken historical data of Dow Jones Suitability Index fifty-six companies from seven sectors, eight companies in each sector from the official website of DJSI World Index and Family Index We have taken twenty-three months of training data from 2009 to 2015, twelve months' data. The ARIMA model is mathematically and statistically derived from past data and predicted by aggregation at a significant number of data points.

\section{Methodology and Results}

Firstly, we obtained the optimal lags for $\mathrm{p}$ and $\mathrm{q}$, we forecast the export series and compare the forecasts from ARIMA model and ARIMAX model. The Mean Squares Forecast Errors statistics are calculated and shown in Figure 1. 
Figure 1. Monthly Integrated DJSI World Index

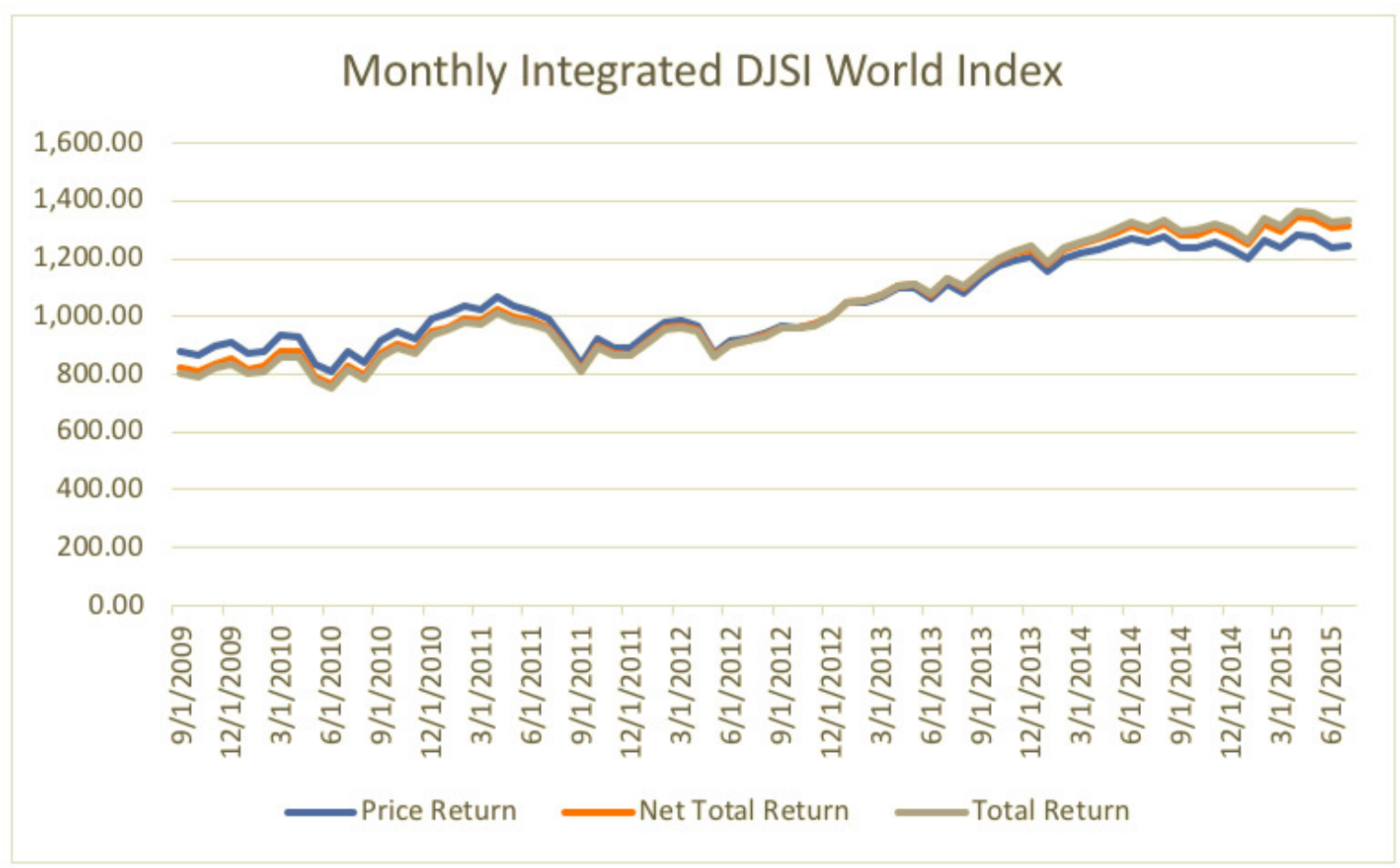

Data series average score was 1.263 .32 , median score was 1.277 .61 points, standard deviation was 147.49 points and amplitude score is 1110.17 points. By analyzing the market, it is clear that there is no seasonality. As soon as a decline occurs between 2011 and 2012, the upward movement of the year from 2012 is followed by a movement upwards, indicating a self-correction between the indices.

Table 1. ARIMA Module Results

\begin{tabular}{|l|l|l|l|l|}
\hline Model & Ar & Drift & AIC & Theil's U \\
\hline ARIMA $(1,1,0)$ & 0.155 & 1.876 & 564.00 & 0.69 \\
\hline Standart Error & 0.072 & & & \\
\hline
\end{tabular}

Table 1 shows us the best model automatically selected by the software in each case. In addition, the estimated coefficients calculated using the data in the sample give us the standard error, AIC and Theil's U. When we compare the results of ARIMA models with exponential smoothing and pure models, we see that the most suitable model is ARIMA $(1,1,0)$ and that the model has the lowest AIC, and that Theil is still lower than 1 . It shows us that the DJSI index has the coking unit and can be kept (unstable). 
Figure 2. DSJI World Family Index

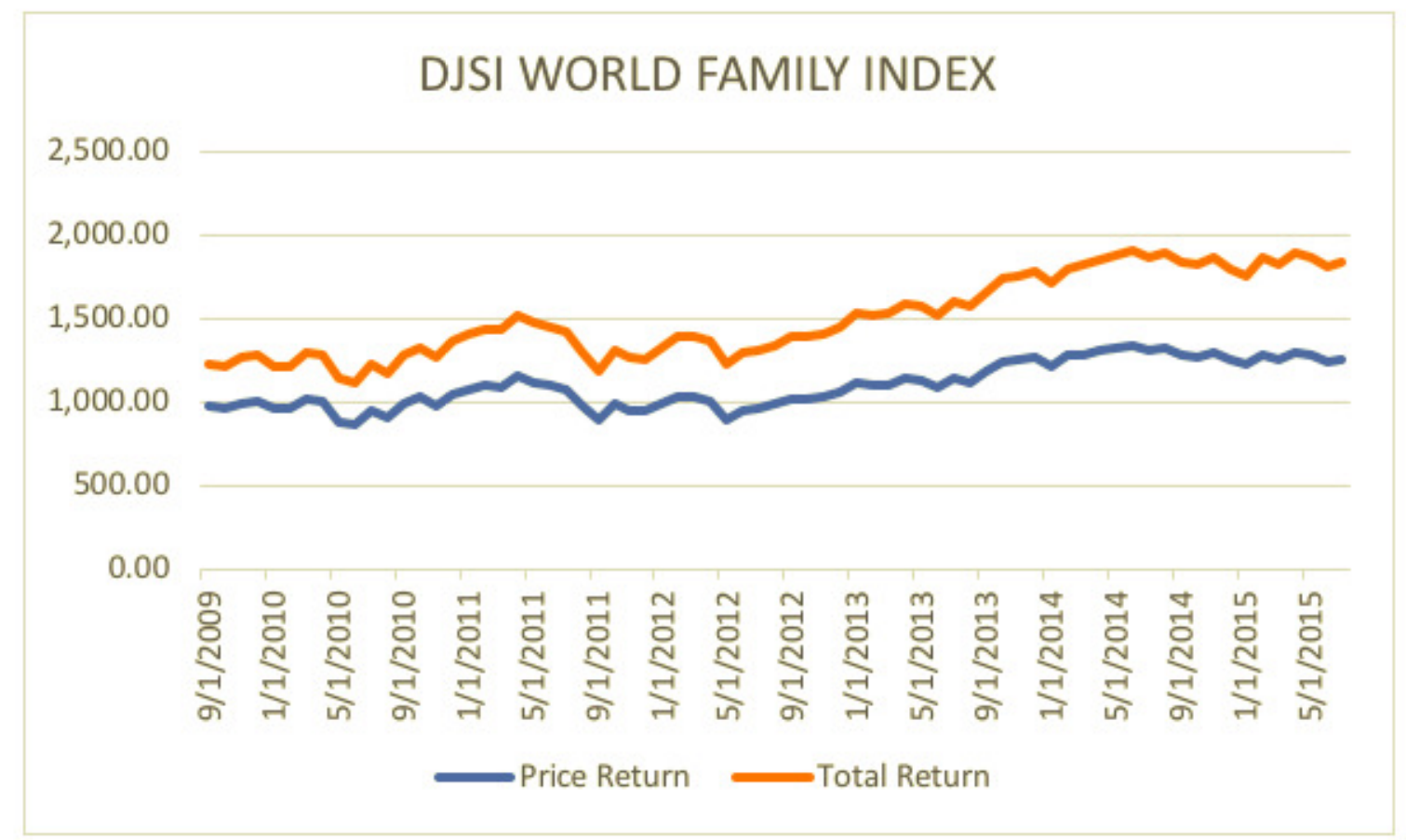

Data series mean score was 1.538.91, median score was 1.499 .02 points, standard deviation was 487.10 points and amplitude score was 1314.00 points. By analyzing the market, it is clear that there is no seasonality. The Dow Jones family index shows that the celestial index gore is performing better and that the scholars have been selling at a better price than the diversified series gore. We confirm this with ARIMA analysis.

Table 2. ARIMA Module Results

\begin{tabular}{|l|c|c|c|c|}
\hline Model & Ar & Drift & AIC & Theil's U \\
\hline ARIMA (1,1,0) & 0.139 & 1.269 & 696.08 & 0.82 \\
\hline Standart Error & 0.094 & & & \\
\hline
\end{tabular}

Table 2 shows us that the most suitable model is ARIMA $(1,1,0)$; which means that the model is an autoregressive component ( $\mathrm{AR}=0.139$ ) and an integration component (I). It was necessary to distinguish the series in order to stabilize it. The model presented us AIC 696.08 and Theil's U's 0.82; this is a more appropriate model than the naive model for making predictions, which is predicted to be a good result when considering the ratios. 


\section{Journal of Accounting, Finance and Auditing Studies 4/4 (2018) 1-10}

\section{Result}

This study compared the use of tools to predict the future behavior of the Dow Jones Sustainability Index (DJSI) at 12-month intervals using ARIMA and Exponential Smoothing models. Exponential Correction, ARIMA and naive estimation methods are used. The study used monthly data for the period September 2009 to August 2015 from the Dow Jones (Dow Jones, 2016) website. The best method was chosen according to Theil and AIC criteria. The Theil's U of ARIMA is set at 0.69 - AIC 564.00 and Theil's of 0.82 - AIC 696.08. The selected model is used together with ARIMA $(1,1,0)$ with drift. That is, an automatic deflection parameter and the first difference are received. Based on the tests, this model has been verified.

As a limitation of the study, it was important that DJSI has a behavior that is difficult to predict because there are many factors that may affect the index results and change the analysis. In addition to this, a model for future work can be developed. With the DJSI and other sustainability indices, the ARIMA model can be realized. Such a method may be more efficient in predicting future uplifts or reductions.

It is important to note that among the constraints of the work, DJSI has predictive and difficult behavior; because there are a number of factors that can affect the outcome of the index. However, this study sought to deeply examine the composition of the index based on a particular methodology used by the RobecoSam Sustainability Investment or the criteria used to select companies.

As a proposal for further research, in general, the method used can be used in advanced markets for advanced forecasting. In this model, it is necessary to create basic limitations, to create a time line, and to be a point of time for every historical data. It is important to examine the composition of the index in more detail, to analyze the longer-term trends and to see how the changes in the results will lead to the remainder, while other explanatory variables such as exchange rate risk, credit risk and other stock indices It is also important to carry out researches involving. Such tools are panel-driven and will help to build more robust models with regression. 


\section{Journal of Accounting, Finance and Auditing Studies 4/4 (2018) 1-10}

\section{References}

Aydemir, M. (2007); "İşletmelerin İş görenlere Karşı Sosyal Sorumlulukları ve SA 8000 Standardı, İstanbul: İktisadi Girişim ve İş Ahlakı Derneği Yayını.

Carroll, B.A., ve Shabana M.K., (2010). "The Business Case for Corporate Social Responsibility: A Review of Concepts, Research and Practice". International Journal of Management Reviews (2010),85-105.

Çamlıca, Z. ve Akar, G. S. (2014). Lojistik Sektöründe Sürdürülebilirlik Uygulamaları. Gümüşhane Üniversitesi Sosyal Bilimler Elektronik Dergisi, 11, 100-120.

Dahlsrud, A., (2006). How Corporate Social Responsibility is Defined: An Analysis of 37 Definitions, 41

Dyllick, T. ve Hockerts, K. (2002). Beyond the Business Case for Corporate Sustainability. Business Strategy and Environment, 11 (2),130-141.

E.D. McKenzie, (1984). General exponential smoothing and the equivalent ARMA process, J. Forecasting 3, 344.

Eş, A. (2008); " Sürdülebilirlik ve Firma Düzeyinde Sürdülebilirlik Performansı", Abant İzzet Baysal Üniversitesi Sosyal Bilimler Enstitüsü Ölçümü.

G.E.P. Box, G. Jenkins, (1970). Time Series Analysis, Forecasting and Control, Holden-Day, San Francisco, CA.

Kavi, E. (2010); "Çocuk İstihdamı Sosyal Sorumlulukm Standartları", Sosyal Siyaset Konferansları Dergisi, -journals.istanbul.edu. tr.

Kuşat, N. (2012); "Sürdülebilir İşletmeler için Kurumsal Sürdülebilirlik ve İçsel Unsurları", Afyon Kocatepe Üniversitesi, İIBF Dergisi.

Knoepfel, I. (2001); Dow Jones Sustainability Group Index: a global benchmark for corporate sustainability, Corporate Environmental Strategy, 8(1), 6-15.

López, M. V.; Garcia, A.; Rodriguez, L. (2007); Sustainable development and corporate performance: A study based on the Dow Jones sustainability index, Journal of Business Ethics, 75(3), 285.

Sarıkaya, M., ve Kara, Z.F. (2007); “Sürdürülebilir Kalkınmada İşletmenin Rolü: Kurumsal Vatandaşlık", Yönetim ve Ekonomi Dergisi. 14(2),221-233.

Tüm, K. (2014); “Kurumsal Sürdülebilirlik ve Muhasebeye Yansımaları: Sürdülebilirlik Muhasebesi", Journal of Academic Approaches Bahar, Cilt: 5, Sayı 1. 51. 
Journal of Accounting, Finance and Auditing Studies 4/4 (2018) 1-10

Yönet, E. (2010); "Kurumsal Sosyal Sorumluluk Anlayışında Son Dönemeç: Stratejik Sorumluluk", Sosyal Bilimler Dergisi.239-264. 